\title{
Strategi Meningkatkan Kepuasan Dalam Membentuk Perilaku Nasabah Pada Lembaga Keuangan Perbankan Di Jawa Tengah
}

\author{
Siti Fatonah, Yuniatin Trisnawati DKW \\ STIE “AUB” Surakarta \\ 2019
}

\begin{abstract}
Abstrak
Penelitian ini bertujuan untuk mengetahui pengaruh kualitas pelayanan, citra dan relationship marketing terhadap kepuasan dan dampaknya pada perilaku nasabah dalam membentuk loyalitas pada Lembaga keuangan di Jawa Tengah. Pengambilan sampel dalam penelitian ini dengan menggunakan teknik Random sampling. Jumlah sampel yang diambil dalam penelitian ini adalah sebanyak 100 responden yang merupakan nasabah Lembaga Keuangan Perbankan di Jawa Tengah. Alat analisis yang dipakai adalah uji instrumen penelitian, uji linearitas, analisis jalur dan regresi dengan uji t, uji $F$ dan Uji $R^{2}$. Hasil Uji $t$ menunjukkan bahwa kualitas pelayanan, citra dan relationship marketing berpengaruh positif terhadap kepuasan nasabah. Dan kualitas pelayanan, relationship marketing dan kepuasan berpengaruh positif terhadap perilaku nasabah. Sedangkan citra berpengaruh negatif terhadap perilaku nasabah. Hasil pengaruh langsung dan tidak langsung dapat disimpulkan bahwa variabel kepuasan sebagai variabel intervening kualitas pelayanan dan relationship marketing adalah tidak efektif, dan lebih efektif kualitas pelayanan dan relationship marketing berpengaruh secara langsung terhadap Perilaku nasabah dalam membentuk loyalitas pada Lembaga Keuangan Wilayah Jawa Tengah. Dan sedangkan variabel Citra lebih efektif berpengaruh terhadap perilaku nasabah apabila melalui kepuasan sebagai variabel intervening. Sedangkan untuk Jalur langsung Relationship Marketing terhadap perilaku merupakan jalur yang paling dominan dan paling efektif dalam meningkatkan perilaku nasabah untuk loyal pada lembaga Keuangan Perbankan, karena mempunyai nilai koefisien regresi yang paling tinggi.

Kata kunci : kualitas pelayanan, citra, relationship marketing, kepuasan dan perilaku nasabah.
\end{abstract}

\begin{abstract}
Strategies to Increase Satisfaction in Forming Customer Behavior in Banking Financial Institutions in Central Java. This study aims to determine the effect of service quality, image and relationship marketing on satisfaction and its impact on customer behavior in shaping loyalty to financial institutions in Central Java. Sampling in this study using the Random sampling technique. The number of samples taken in this study is as many as 100 respondents who are customers of Banking Financial Institutions in Central Java. The analytical tool used is the research instrument test, linearity test, path analysis and regression with t test, $\mathrm{F}$ test and R2 test. $\mathrm{T}$ test results show that service quality, image and relationship marketing have a positive effect on customer satisfaction. And service quality, relationship marketing and satisfaction have a positive effect on customer behavior. While the image has a negative effect on customer behavior. The results of direct and indirect effects can be concluded that the satisfaction variable as an intervening variable service quality and relationship marketing is ineffective, and more effective service quality and relationship marketing directly affects customer behavior in shaping loyalty to the Central Java Regional Financial Institution. And while the Image variable is more effective in influencing customer behavior if it is through satisfaction as an intervening variable. Whereas for the direct path of Relationship Marketing towards behavior is the most dominant and most effective way to improve customer behavior to be loyal to the Banking Financial institution, because it has the highest regression coefficient value.
\end{abstract}

Keywords: service quality, image, relationship marketing, customer satisfaction and behavior 


\section{PENDAHULUAN}

Di era globalisasi persaingan bisnis baik di pasar domestik maupun di pasar internasional baik untuk pasar produk maupun jasa sangat ketat. Perusahaan yang ingin berkembang dan bertahan hidup harus dapat memberikan kepada para pelanggan berupa barang atau jasa yang berkualitas dan pelayanan yang lebih baik daripada pesaingnya. Hal ini dilakukan dalam upaya untuk memberikan kepuasan kepada pelanggan. Kondisi ini menjadikan kepuasan sebagai hal yang penting dan menjadi keharusan agar perusahaan produk maupun jasa tetap sukses, baik ditingkat operasional, manajerial maupun strategik.

Keberadaan dan munculnya banyak jasa keuangan baik dari lembaga keuangan bank dan lembaga keuangan non bank, koperasi, keuangan mempunyai peran yang penting dalam mendukung pertumbuhan ekonomi. Hal ini sekaligus menyadarkan masyarakat akan manfaat yang diberikan oleh jasa keuangan bagi pemenuhan kebutuhan para nasabah.

Keberadaan keuangan di era persaingan yang ketat ini menuntut perusahaan keuangan untuk berbenah diri menyongsong persaingan yang semakin ketat. Hal ini, tentunya dibutuhkan keunggulan suatu pelayanan dimana akan sangat tergantung pada keunikan serta kualitas yang diperlihatkan oleh jasa keuangan tersebut tersebut. Jasa secara spesifik harus memperlihat kebutuhan dan keinginan nasabah karena jasa yang dirasakan dan dinikmati langsung oleh nasabah akan segera mendapat penilaian sesuai atau tidak sesuai dengan harapan dan penilaian pelanggan.

Menurut Kotler, (2007:24) kualitas harus dimulai dari kebutuhan nasabah dan berakhir pada persepsi nasabah. Hal ini berarti bahwa citra kualitas yang baik bukan dilihat dari persepsi penyedia jasa melainkan berdasarkan persepsi nasabah. Persepsi nasabah terhadap kualitas pelayanan merupakan penilaian menyeluruh atas keunggulan suatu jasa.

Salah satu cara membedakan sebuah perusahaan jasa keuangan dengan perusahaan jasa keuangan lainnya adalah bagaimana memberikan pelayanan dengan kualitas yang lebih tinggi dari pesaing secara konsisten. Menurut Parasuraman, Zeithaml dan Berry, dalam Fandy (2005: 67), ada dua faktor yang mempengaruhi kualitas pelayanan, yaitu pelayanan yang diharapkan dan pelayanan yang dirasakan. Jika pelayanan yang diterima sesuai dengan yang diharapkan, maka kualitas pelayanan dipersepsikan baik dan memuaskan, jika pelayanan yang diterima melampaui harapan pelanggan, kualitas pelayanan dipersepsikan ideal, sebaliknya apabila pelayanan yang diterima lebih rendah daripada yang diharapkan, kualitas pelayanan dipersepsikan buruk.

Dalam konteks pengukuran variabel kualitas pelayanan, Parasuraman, Zeithaml dan Berry dalam Fandy (2005:54) mengidentifikasikan lima dimensi ukuran kualitas layanan yaitu reliability (keandalan), responsiveness (daya tanggap), assurance (jaminan), tangibles (bukti langsung), dan empathy (empati). Pengukuran semacam ini dikenal sebagai model service quality (Servqual). Dabhokar, et al. (2006:61) mengajukan dimensi ukuran kualitas jasa pada bisnis ritel yang meliputi physical aspects, reliability, personal interaction, relationship dan policy yang merupakan kombinasi dari literatur ritel dan Servqual. Menurut, Engel, et.al. dalam Fandy (2005:42) mengatakan bahwa kepuasan nasabah merupakan evaluasi purna beli setelah alternatif yang dipilih sekurang-kurangnya memberikan hasil sama atau melampaui harapan pelanggan. Kepuasan nasabah merupakan tingkat perasaan seseorang setelah membandingkan kinerja atau hasil yang dibanding harapannya (Kotler,2007:68).

Peran aktivitas lembaga keuangan ini, mendorong penciptaaan persaingan antar lembaga ini semakin nyata. Tuntutan kinerja perusahaan keuangan yang baik menjadi harapan bagi setiap perusahaan keuangan untuk dapat melakukannya sebagai konsekuensi tuntutan masyarakat yang semakin kritis untuk memilih perusahaan keuangan yang baik. Dengan demikian, perlu dikaji dan dikembangkan : orientasi pada sisi konsumen misalnya kepuasan nasabah yang dapat menstimuli menggunakan jasa keuangan. Perusahaan keuangan sebaiknya mengukur tingkat perasaan seseorang setelah membandingkan hasil yang dirasakan dengan harapannya. Tanggung jawab utama setiap pelaku bisnis mengarah kepada pencapaian maksimal, yakni Kepuasan nasabah (Kotler, 2007). 
Salah satu strategi lain yang dapat mempengaruhi kepuasan adalah adanya relationship yang dilakukan oleh bank. Relationship ini akan memberikan solusi dalam permasalahan yang dianggap penting dan strategis bagi bank. Nasabah akan merasa terlindungi terhadap masalah yang dihadapi oleh nasabah. Relationship adalah upaya menjalin relasi jangka panjang dengan para pelanggan. Asumsinya adalah bahwa relasi yang kokoh dan saling menguntungkan antara penyedia jasa dan pelanggan dapat membangun bisnis ulangan (repeat bussines) dan menciptakan Perilaku pelanggan. Karakteristik Relationship Tjiptono, F (2001: 145).

Lembaga Keuangan Keuangan di Jawa Tengah, yang merupakan sebuah perusahaan keuangan berpengalaman menyadari tantangan persaingan ini memerlukan perhatian khusus. Beberapa fenomena yang ada di Lembaga Keuangan Keuangan di Jawa Tengah dapat ditunjukkan uraian dibawah ini Orientasi pada masalah nasabah menjadi skala prioritas utama disamping menciptakan unggulan produk yang menarik perlu dikembangkan untuk dapat bersaing dengan perusahaan yang lain. Bahkan saat ini Lembaga Keuangan Keuangan di Jawa Tengah betul-betul menyadari bahwa perlunya untuk mengemas pelayanan unggulan menjadi skala prioritas utama. Untuk itu lima dimensi ukuran kualitas layanan yaitu reliability (keandalan), responsiveness (daya tanggap), assurance (jaminan), tangibles (bukti langsung), dan empathy (empati), akan menjadi variabel utama yang mengarahkan segala sumber daya menuju pada orientasi kualitas pelayanan di atas.

Orientasi pada masalah target pasar dalam meraih pangsa pasar yang lebih besar menjadi fokus utama langkah Lembaga Keuangan Keuangan di Jawa Tengah karena untuk dapat bersaing dengan perusahaan keuangan yang lain, dibutuhkan strategi yang baik.

Orientasi pada masalah perilaku nasabah mempunyai peran yang sangat besar bagi Lembaga Keuangan Keuangan di Jawa Tengah, sebagai evaluasi terhadap kepentingan strategi kedepan. Lembaga Keuangan Keuangan di Jawa Tengah, memetakan data tentang nasabah. Lembaga Keuangan Keuangan di Jawa Tengah mencoba memahami bahwa perilaku nasabah adalah bersifat dinamis. Kedua, adanya interaksi antara efektif dan kognisi nasabah, sehingga perilaku nasabah mempunyai persepsi baik sangat tergantung bagaimana . Lembaga Keuangan Keuangan di Jawa Tengah memberikan pelayanan. Ketiga, Lembaga Keuangan Keuangan di Jawa Tengah mempunyai sumber daya manusia yang kompeten. Dengan kata lain, kegiatan transaksi merupakan hasil dari tahapan yang terjadi selama proses mental dan fisik konsumen. Saat sifat perilaku nasabah yang dinamis ini dihubungkan dengan sumber daya manusia yang handal maka nasabah akan terpuaskan kebutuhan dan keinginannya, untuk itu Lembaga Keuangan Keuangan di Jawa Tengah mengevaluasi persepsi nasabah terhadap hubungan yang baik dengan nasabah yang perlu dikembangkan. Hal ini akan berkaitan dengan faktor relationship yang akan dijadikan fokus strategi kedepan. Relation marketing merupakan cara bagaimana suatu perusahaan menjalin hubungan baik dengan nasabahnya agar nasabah melakukan transaksi secara berkelanjutan, sehingga akan tercipta costumer loyalty yang merupakan kesetiaan nasabah terhadap suatu produk Lembaga Keuangan Keuangan di Jawa Tengah.

Atas dasar latar belakang tersebut, maka peneliti mengambil judul penelitian : Strategi Meningkatkan Kepuasan Dalam Membentuk Perilaku Nasabah Pada Lembaga Keuangan Perbankan Di Jawa Tengah.

\section{METODE}

Pengambilan sampel dalam penelitian ini dengan menggunakan teknik Random sampling. Jumlah sampel yang diambil dalam penelitian ini adalah sebanyak 100 responden yang merupakan nasabah Lembaga Keuangan Perbankan di Jawa Tengah. jumlah sampel didasarkan pada pendapat Fraenkel dan Wallen (2003) dalam Widayat (2004) menyatakan bahwa jika populasi sulit dihitung dan melebihi 100, maka jumlah sampel minimal adalah sebanyak 100 orang. Sampel yang digunakan dalam penelitian 
ini berjumlah 100 nasabah bank. Penelitian ini menggunakan alat analisis berupa uji validitas, uji reliabilitas, uji linieritas, analisa jalur, analisa regresi linier berganda, uji t, uji $\mathrm{F}$ dan koefisien determinasi.

Analisis regresi jalur adalah, analisis jalur merupakan pengembangan langsung bentuk regresi berganda dengan tujuan untuk memberikan estimasi tingkat kepentingan (magnitude) dan signifikasi (significance) hubungan sebab akibat hipotetikal dalam seperangkat variabel.

Hubungan kausalitas akan digunakan analisis jalur dan intervening. Pada penelitian ini variabel kepuasan ditempatkan sebagai variabel intervening untuk variabel kualitas pelyanan, citra dan Relationship Marketing terhadap Perilaku nasabah.

Analisis regresi linear berganda digunakan untuk menganalisa pengaruh beberapa variabel bebas atau independen variabel $(\mathrm{X})$ terhadap satu variabel tidak bebas atau dependen variabel $(\mathrm{Y})$ sebagai berikut:.

$Y_{1}=\alpha+\beta_{1} X_{1}+\beta_{2} X_{2}+\beta_{3} X_{3}+\quad$ (Persamaan I)

$Y_{2}=\alpha+\beta_{1} X_{1}+\beta_{2} X_{2}+\beta_{3} X_{3}+\beta_{4} X_{4}+$ (Persamaan II)

\section{HASIL PENELITIAN}

Berdasarkan hasil analisa jalur dapat diperoleh hasil sbb:

Persamaan 1 yaitu :

$\mathrm{Y}_{1}=0,211 \mathrm{X}_{1}+0,635 * * \mathrm{X}_{2}+0,585 * * \mathrm{X}_{3}+\epsilon$

persamaan 2 yaitu :

$\mathrm{Y}_{2}=0,249 \mathrm{X}_{1}-0,068 \mathrm{X}_{2}+0,611 * * \mathrm{X}_{3}+0,451 * * \mathrm{Y}_{1} .+\epsilon$

\section{Model Hasil Analisis:}

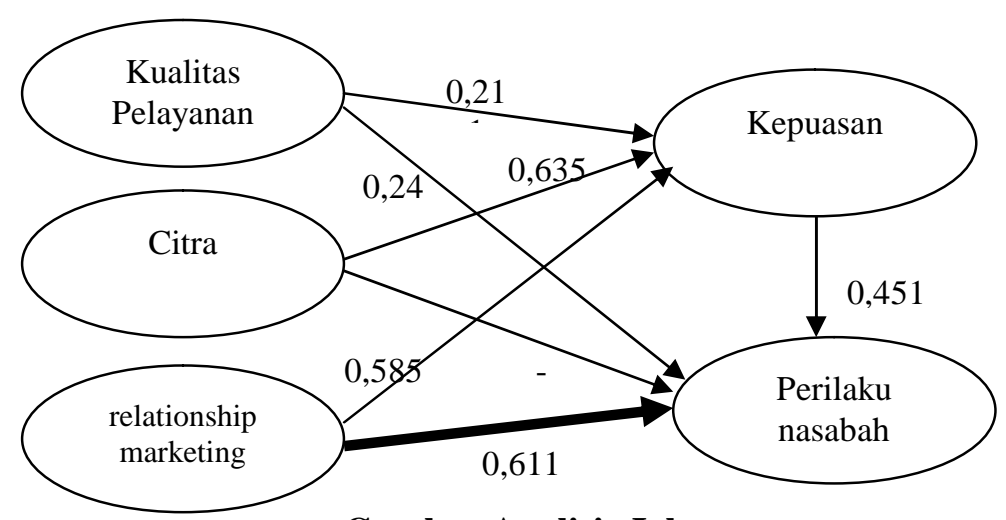

Gambar Analisis Jalur

\section{PEMBAHASAN}

\section{Pengaruh Kualitas pelayanan Terhadap Perilaku nasabah melalui kepuasan nasabah}

Dari analisis jalur ini menunjukkan bahwa penggunaan variabel intervening kepuasan nasabah dalam rangka peningkatan perilaku nasabah dalam membentuk loyalitas, untuk variabel kualitas pelayanan menunjukkan tidak efektif, karena pengaruh langsung kualitas pelayanan terhadap perilaku nasabah menghasilkan pengaruh yang lebih besar dari pada melalui variabel intervening kepuasan nasabah.

Pada prinsipnya kualitas pelayanan berpusat pada upaya pemenuhan keinginan dan kebutuhan nasabah serta ketepatan penyampaiannya untuk mengimbangi harapan nasabah. Hal ini menggambarkan bahwa kualitas pelayanan adalah kemampuan perusahaan dalam memberikan pelayanan yang bermutu kepada para nasabahnya. Pelayanan yang baik merupakan keseluruhan kesan nasabah terhadap inferioritas /superioritas organisasi beserta jasa yang ditawarkan, sehingga kualitas 
pelayanan merupakan tingkat keunggulan yang diharapkan untuk membentuk perilaku nasabah. Semakin baik kualitas pelayanan mencerminkan kemampuan perusahaan dalam memberikan jasa kepada nasabah yang telah membeli produknya dan diharapkan dapat membentuk perilaku nasabah yang pada akhirnya akan meningkatkan perilaku dalam membentuk loyalitas pada lembaga keuangan perbankan.

Hasil ini sejalan dengan temuan empiris dari Hasil penelitian yang relevan dilakukan oleh Taylor dan Baker (2004) yang menyatakan dalam hasil penelitianya bahwa Kualitas pelayanan berpengaruh signifikan terhadap perilaku nasabah. Untuk itu sebaiknya ada upaya - upaya yang harus dilakukan untuk evaluasi terhadap kualitas pelayanan dengan mempertahankan :

a. Fasilitas yang tidak nyaman saat bertransaksi, maka perlu diperbaiki.

b. Pegawai yang tidak memiliki kemampuan melayani nasabah dengan cepat, maka perlu adanya training dan workshop pelayanan bagi para pegawai secara periodik.

c. Respon setiap keluhan saat bertransaksi, perlu direspon segera atau diadakan kotak saran yang setiap hari dibuka, sehingga keluhan dapat di respon dan dipecahkan solusi permasalahannya.

d. Rasa empati, perlu ditingkatkan dengan memberikan ucapan pada hari hari bahagia nasabah seperti ulang tahun dan hari kebahagiaan lainya.

\section{Pengaruh citra bank terhadap Perilaku nasabah melalui kepuasan nasabah}

Penggunaan variabel intervening kepuasan nasabah dalam rangka peningkatan perilaku nasabah, untuk variabel citra bank efektif, karena pengaruh langsung citra bank terhadap perilaku nasabah nasabah menghasilkan pengaruh yang lebih kecil dari pada melalui variabel intervening kepuasan nasabah, sehingga citra bank dapat meningkatkan perilaku nasabah dengan melalui kepuasan nasabah.

Citra bank adalah suatu gambaran tentang mental; ide yang dihasilkan oleh imajinasi atau kepribadian yang ditunjukkan kepada publik oleh seorang, perusahaan, organisasi dan sebagainya. Mackiewicz (2003) dalam Oliver (2007:51) percaya bahwa citra korporasi yang kuat adalah asset yang penting dalam era kompetisi tanpa batas. Namun, seberapa samar- samarnya sebuah citra, citra merupaka realitas karena orang hanya dapat bereaksi terhadap apa yang telah mereka alami dan rasakan. Kotler (1988) dalam Oliver (2007:53) menyatakan bahwa citra perusahaan dapat sangat spesifik atau sangat berlebihan dan bahwa beberapa organisasi mungkin tidak ingin atau tidak memerlukan citra yang spesifik. Citra adalah perusahaan di mata publik. Citra adalah sebuah cerminan dari identitas sebuah organisasi atau perusahaan. Sebuah organisasi atau perusahaan dapat memiliki beberapa citra yang berbeda-beda di mata publik yang berbeda-beda pula. Semakin baik citra perusahaan maka akan semakin tinggi perilaku nasabah.

Hasil penelitian ini tidak sejalan dengan temuan empiris dari Hasil penelitian yang relevan dilakukan oleh Nuraini (2008) yang menyatakan dalam hasil penelitiannya bahwa citra berpengaruh signifikan terhadap perilaku nasabah.

Oleh karena itu, untuk meningkatkan perilaku nasabah Lembaga Keuangan Perbankan Wilayah Jawa Tengah harus meningkatkan kepuasan terlebih dahulu dengan menggerakkan citra bank di masyarakat misalnya dengan cara:

a. Meningkatkan nama baik perusahaan di mata masyarakat

b. Meningkatkan popularitas perusahaan dan pimpinan

c. Meningkatkan kepercayaan nasabah

d. Manajer / pengelola meningkatkan kinerjanya

\section{Pengaruh Relationship Marketing terhadap Perilaku nasabah melalui kepuasan nasabah}

Penggunaan variabel intervening kepuasan nasabah dalam rangka peningkatan perilaku nasabah, untuk variabel Relationship Marketing menunjukkan tidak efektif, karena pengaruh langsung Relationship Marketing terhadap perilaku nasabah menghasilkan pengaruh yang lebih besar dari pada melalui variabel intervening kepuasan nasabah yaitu Hal ini berarti bahwa dalam rangka 
meningkatkan perilaku nasabah sebaiknya tidak melalui variabel intervening kepuasan nasabah tetapi langsung pada variabel Relationship Marketing, ini berarti bahwa untuk meningkatkan perilaku nasabah, maka faktor yang mempengaruhi Relationship Marketing perlu mendapat perhatian yang tinggi.

Relationship Marketing merupakan upaya menjalin relasi jangka panjang dengan para nasabah. Aktifitas yang dilakukan berfokus pada upaya menjalin hubungan jangka panjang dengan nasabah, nasabah bersifat unik dan tidak identik satu sama lain, menekankan serangkaian transaksi sepanjang waktu, Lebih banyak didasarkan pada psikologi dan sosiologi, sehingga asumsinya adalah bahwa relasi yang kokoh dan saling menguntungkan antara penyedia jasa dan nasabah dapat membangun bisnis ulangan (repeat bussines) dan menciptakan perilaku nasabah.

Hasil ini sejalan dengan temuan empiris dari Hasil penelitian yang relevan dilakukan oleh Roony Palmer (2010), Taylor dan Baker (2004), (2009), Nuraini, (2008) yang menyatakan dalam hasil penelitianya bahwa Relationship Marketing berpengaruh signifikan terhadap perilaku.

Langkah yang dilakukan adalah meningkatkan Relationship Marketing dengan cara:

a. Lembaga Keuangan Wilayah Jawa Tengah sebaiknya mempunyai data para nasabah misalnya bank mempunyai bank data yang berisi data para nasabah potensial yang digunakan untuk dasar pendekatan terhadap nasabah.

b. Pimpinan Lembaga Keuangan Wilayah Jawa Tengah sebaiknya mengerti kebutuhan nasabah, hal ini dilakukan untuk melakukan segmentasi yang menjadi targetnya sehingga dapat diciptakan hubungan nasabah.

c. Karyawan Lembaga Keuangan Wilayah Jawa Tengah sebaiknya selalu menjaga hubungan baik dengan para nasabah misalnya para pegawai di lapangan dihimbau untuk dapat beranjangsana ke tempat nasabah untuk menciptakan pendekatan yang lebih erat lagi.

d. Karyawan Lembaga Keuangan Wilayah Jawa Tengah sebaiknya melakukan perbaikan kerja dalam melakukan transaksi dengan nasabah untuk menjaga hubungan dengan nasabah

\section{PENUTUP}

\section{Simpulan}

Berdasarkan hasil analisis dan pembahasan maka selanjutnya dapat ditarik kesimpulan sebagai berikut:

1) Variabel kualitas pelayanan berpengaruh positif terhadap kepuasan nasabah.

2) Variabel Citra berpengaruh positif terhadap kepuasan nasabah.

3) Variabel Relationship Marketing berpengaruh positif terhadap kepuasan nasabah. Ini berarti semakin

4) Variabel kualitas pelayanan berpengaruh positif terhadap Perilaku nasabah dalam membentuk loyalitas.

5) Variabel Citra berpengaruh negatif terhadap Perilaku nasabah dalam membentuk loyalitas.

6) Variabel Relationship Marketing berpengaruh positif terhadap Perilaku nasabah dalam membentuk loyalitas.

7) Variabel Kepuasan berpengaruh positif terhadap Perilaku nasabah dalam membentuk loyalitas.

8) Hasil pengaruh langsung dan tidak langsung dapat disimpulkan bahwa variabel kepuasan sebagai variabel intervening kualitas pelayanan dan relationship marketing adalah tidak efektif, dan lebih efektif kualitas pelayanan dan relationship marketing berpengaruh secara langsung terhadap Perilaku nasabah dalam membentuk loyalitas pada Lembaga Keuangan Perbankan Wilayah Jawa Tengah, sedangkan variabel Citra lebih efektif terhadap perilaku nasabah apabila melalui kepuasan sebagai variabel intervening

9) Hasil pengaruh langsung dan tidak langsung dapat dijelaskan bahwa variabel yang paling dominan dan lebih efektif adalah variable relationship marketing berpengaruhh secara langsung terhadap Perilaku nasabah dalam membentuk loyalitas pada Lembaga Keuangan Wilayah Jawa Tengah 


\section{Saran}

Berdasarkan kesimpulan tersebut di atas, maka saran-saran yang dapat diberikan antara lain :

1) Untuk meningkatkan Perilaku nasabah dalam membentuk loyalitas pada Lembaga Keuangan Wilayah Jawa Tengah paling efektif melalui peningkatan variabel Relationship Marketing dengan cara :

a) Lembaga Keuangan Wilayah Jawa Tengah sebaiknya mempunyai data para nasabah misalnya bank mempunyai bank data yang berisi data para nasabah potensial yang digunakan untuk dasar pendekatan terhadap nasabah.

b) Pimpinan Lembaga Keuangan Wilayah Jawa Tengah sebaiknya mengerti kebutuhan nasabah, hal ini dilakukan untuk melakukan segmentasi yang menjadi targetnya sehingga dapat diciptakan hubungan nasabah.

c) Karyawan Lembaga Keuangan Wilayah Jawa Tengah sebaiknya selalu menjaga hubungan baik dengan para nasabah misalnya para pegawai di lapangan dihimbau untuk dapat beranjangsana ke tempat nasabah untuk menciptakan pendekatan yang lebih erat lagi.

d) Karyawan Lembaga Keuangan Wilayah Jawa Tengah sebaiknya melakukan perbaikan kerja dalam melakukan transaksi dengan nasabah untuk menjaga hubungan dengan nasabah

2) Untuk meningkatkan Kepuasan nasabah paling efektif melalui peningkatan citra/reputasi dengan cara :

a) Mempertahankan nama baik perusahaan di mata masyarakat

b) Mempertahankan popularitas perusahaan dan pimpinan

c) Mempertahankan kepercayaan nasabah

d) Manajer/pengelola mempertahankan kinerjanya

3) Karena variabel kepuasan tidak efektif sebagai variable intervening, sebaiknya variable kepuasan ditempatkan sebagai variable independent karena mempunyai pengaruh positif dan signifikan secara langsung terhadap perilaku nasabah dalam membentuk loyalitas Lembaga Keuangan Perbankan di Wilayah Jawa Tengah.

\section{DAFTAR PUSTAKA}

Albert, Weldison, 2007. Nasabah Bank Dalam Likuidasi. Hasil Survei. Econit Advisory Group dalam Swasembada. Desember. Jakarta.

Alma, Buchari, 2000. Manajemen Pemasaran dan Pemasaran Jasa. Alfabeta, Bandung.

Anderson, James C., D.C. Jain, and Pradeep K. Chintagunta, 2007. Customer Value

Assessment In Business To Business Markets: A State of Practice Study. Journal Of Business To Business Marketing, Vol. 1, US

Arief, Sritua, 2003. Metodologi Penelitian Ekonomi, Cetakan Pertama. Penerbit Universitas Indonesia. Jakarta.

Arikunto, Suharsimo, 2003. Dasar-Dasar Evaluasi Pendidikan, Penerbit Rineka Cipta, Jakarta

Assael, Henry, 2002. Customer Behaviour and Marketing. Gourth Edition. PWS-Kent Publishing company. Boston-USA.

Astuti, 2002, Pengaruh Nilai Pelanggan, Kualitas Pelayanan, Relationship, Produk terhadap kepuasan dan Transaksi bank di Bank Indonesia wilayah kerja Malang, thesis, Unair.

Azwar, Saifudin, 2005. Basic Econometrics, $3^{\text {rd }}$ ed. McGraw-Hill International. New York. 
Bitner, Mary Jo, 2000. Building Service Relationship: It's All About Promises. Journal Of The Academy Of Marketing Science. Vol. 23, No. 4, Miami.

Cronin, J. Joseph dan Steven A. Taylor, 2002, Measuring Service Quality: A Reexamination and Extention, Journal of Marketing, Vol. 56, 55-68.

Measurement of Service Quality, Journal of Marketing, Vol. 58, 125-131

Elliott, 2003, three customer values are key to market success, The Journal of Retail Banking Service

Ferdinand, Augusty, (2000), Struktural Equation Modeling, BP Undip Semarang

Fornell, C., 2006, A National Customer Satisfaction Barometer: The Swedish Experience, Journal of Marketing, 56, 6-21

Frieder, Larry A., Gregor, William T., 2006. Bank Valuations : Meeting Customer and Investor Needs (Part I). Bankers Magazine. Vol. 179. July/August. UMI-US.

2006. Bank Valuations : Meeting Customer and

Investor Needs (Part II). bankers Magazine. Vol. 179. July/August. UMI-US.

Garvin ,2007, Competing on quality, Harvard Business Review,65

Gale, Bradley T., 2004. Managing Customer value. Fress Press. New York.

Gronroos, Christina, 2000. Service Management and Marketing. Managing The Moment

Of Truth In Service Competition. Lexington Books. New York.

Ghozali, Imam, 2004, Analisis Multivariat, Badan Penerbit Undip, Semarang

Gujarati, Damodar, 2005. Basic Econometris, $3^{\text {rd }}$ edition. McGraw Hill International. New York.

Hadi, Sutrisno, 2000. Analisis Butir. Ganesha. Bandung.

Hair et al., 2005. Multivariate Data Analysis Witrh Reading, $4^{\text {th }}$ edition. Prentice-Hall International. New Jersey.

Humphreys, Michael A., Williams, Michael R., 2008. Exploring The Relative effect Of Salesperson Interpersonel Process Atributes and Technical product Attributes On Customer Satisfaction, Journal Of Personal Selleling and Sales Management. Vol. XVI. No. 3. US.

Kadi, ismail, 2000. Perilaku Konsumen Dalam Menabung Pada bank Persero Surabaya.

Thesis. Universitas Airlangga, Surabaya.

Kerlinger, Fred N., 2000. Foundation Of Behavioral Research. Third Edition. Holth.

Rinehart and Winston Inc. Oregon.

Kotler, Philip, 2002. Marketing Management : Analysis, Planning, Implementation and

Control. Tenth Edition. Prentice Hall Inc. New Jersey. 
2000. Marketing Management ; The Millenium Edition. Internasional

Edition. Pretince Hall Inc. New Jersey.

Kuncoro, M, 2001, Metode Riset Untuk Bisnis \& Ekonomi : Bagaimana Meneliti \&

Menulis Tesis?”, Erlangga, Jakarta

Lupiyoadi, Rambat, 2001, Manajemen Pemasaran Jasa, Penerbit Salemba Empat, Jakarta

Marso, 2003. Analisis Kepuasan Penabung Terhadap Atribut-Atribut Bank Pemerintah

(Study Kodya Tarakan). Thesis. Univ. Airlangga. Surabaya.

Moorman, Christine, Rohit Deshpande, and Gerald Zaltman. 2003. Relationship Between Providers and Users Of Market Research: The Role f Personal Trust. Marketing Science Institute. Cambrige

Nauman, Earl. 2005. Creating Customer Value : The Path To Sustainable Competitive. Thomas Executive Press. Cincinnati-Ohio.

Parasuraman, A.,V.A Zeithaml, and L.L Berry. 2003,2008,2000 "A Conceptual Model Of Service Quality And Implication For Future Research", Journal Of Marketing, Vol.49, P. 40 - 50

Peter, J Paul and Olson, Jerry C., 2000. Consumer Behaviour And Marketing Strategy, Fourth Edition. Irwin. Boston.

Ridaryanto, Petrus, 2003. Analisis Perbandingan Strategi Pemasaran Tabungan Antara Bank Pemerintah dan Bank Swasta di Surabaya. Thesis. Universitas Airlangga. Surabaya.

Shaw, Arthur V., 2008. Creates Customer Value By Leveraging The Web and Other

Channels. Journal Retail Bangking Service. Vol. XX. US.

Singarimbun, Masri dan Soryan Effendi, 2002. Metode Penelitian Survei. PPSK-UGM. Jogyakarta.

Sinungan, Muchdarsyah. 2002 Manajemen Dana Bank. Rineka Cipta. Jakarta.

Statistik Perbankan RI, 2006. Ekonomi dan Keuangan. Jakarta.

Sugiyono, 2001, Statistik, . Jakarta : Pustaka Binaman Pressindo.

Supranto , 2004, Statistik induktif, BPFE, Yogyakarta

Tjiptono, Fandi. 2002, Prinsip-Prinsip Total Quality Service, Yogyakarta : Penerbit Andi

Undang-Undang Republik Indonesia No. 10, 2008. Perubahan Undang-Undang No. 7 Tahun 2002 Tentang Perbankan. Jakarta.

Zeithaml, Valerie A.; Bitner, Mary Jo; 2006, Service Marketing, McGraw-Hill (International Editions) 